Современная стратегия диагностики, лечения, профилактики сахарного диабета и его осложнений.

\title{
ХРОНИЧЕСКАЯ СЕРДЕЧНАЯ НЕДОСТАТОЧНОСТЬ У БОЛЬНЫХ САХАРНЫМ ДИАБЕТОМ: ПОДВОДНЫЕ РИФЫ ДИАГНОСТИКИ НА РАЗНЫХ ЭТАПАХ НАБЛЮДЕНИЯ
}

\author{
Занозина О.В., Тарадайко Н.Ю., Кольчик О.В., Сорокина Ю.А., Суханов С.А., Саратовская В.К. \\ ФГБОУ ВО «Приволжский исследовательский медицинский университет» Минздрава России, Нижний Новгород \\ ГГБУз Нижегородской области «Нижегородская областная клиническая больница им. Н. А. Семашко», \\ Нижний Новгород \\ ФГБОУ ВО «ПИМУ» Минздрава России, Нижний Новгород \\ ГБУз НО НОКБ им. Н. А. Семашко, Нижний Новгород
}

Сахарный диабет (СД) способствует формированию миокардиальной дисфункции, приводящей к развитию и прогрессированию хронической сердечной недостаточности (XCH). Однако формирование данного осложнения происходит исподволь и при отсутствии явной клинической картины не учитывается врачами-эндокринологами и терапевтами при амбулаторных осмотрах. Так, по данным Нижегородского регистра больных сахарным диабетом наличие ХСН в 2017/2018/2019гг зарегистрировано у 0,06\%/0,12\%/0,19\% больных СД 1 типа соответственно и у 0,4\%/0,5\%/ 0,65\% больных СД 2 типа соответственно, в то же время основная причина смертности у больных СД 1 типа - ХСН - регистрируется в 18,28\%/19/19,2\% случаев, а у больных с СД 2 типа - в 32\%/33,2\%/34,3\% случаев. Следовательно, стоит вопрос о необходимости ранней, доклинической диагностики XСН для начала (корректировки) патогенетической терапии для предотвращения прогрессирования сердечной недостаточности.

В качестве скринингового маркера ХСН мы использовали мозговой натрийуретический пептид. При скрининговом обследовании 34-х пациентов в возрасте 45-77 лет, поступивших в ГБУЗ НО НОКБ им. Н. А. Семашко для планового лечения с диагнозом сахарный диабет, при отсутствии клинической симптоматики сердечной недостаточности у 19 пациентов данный маркер был выше верхней границы нормы как минимум в 2,5 раза, что свидетельствовало о наличии ХCH и послужило причиной коррекции проводимой терапии.

Следовательно, целесообразно шире использовать данный маркер во врачебной практике для выявления ранних стадий хронической сердечной недостаточности у больных СД старше 45 лет и/или с длительным течением заболевания для определения дальнейшей персонифицированный тактики лечения, так как это поможет отсрочить прогрессирование сердечно-сосудистых осложнений и повлиять на снижение сердечно-сосудистой смертности. 